\title{
Sobre "El cine y las relaciones \\ culturales entre México y Estados Unidos durante la década de 1930"
}

Aurelio De los Reyes

\begin{abstract}
Comentario que propone incluir nuevos temas que deben tratarse, como el impacto del cine estadunidense

en las sociedades actuales en vista del fenómeno de globalización, y que apunta a ciertos problemas metodológicos derivados, parcialmente, de las fuentes.
\end{abstract}

$\mathbf{E}$

1 presente texto es un comentario a la tercera versión de la ponencia titulada originalmente "El cine, el Estado mexicano y la politica exterior de los Estados Unidos" de Seth Fein, cuyas versiones primera y tercera he tenido en mis manos, ya que la segunda se leyó en la sesión.

El comentario a la primera versión lo dividí en dos partes; en la primera expresaba unas consideraciones que me sugirió el texto de Fein; en la segunda manifestaba una serie de problemas metodológicos de que adolecía el mismo, sin perder de vista sus numerosos aciertos.
En esta segunda versión conservo la misma estructura.

Fein señala en su nota 6 del texto, que comento:

En el texto, más extenso, del que es una adaptación este artículo, abordo otros temas de nacionalismo cultural, en particular la respuesta del Estado mexicano a la penetración del inglés a través de las películas sonoras estadunidenses a principios de la década de 1930, y la intervención del Estado Mexicano en la industria filmica sonora en desarrollo,

por lo cual mantengo las consideraciones sugeridas por la primera versión 
ya que las considero vigentes y porque Fein, en un futuro cercano, estoy seguro, regresará sobre los problemas inherentes a la vecindad entre México y Estados Unidos, particularmente a las medidas proteccionistas que tomó el gobierno mexicano para desarrollar el cine mexicano y, a largo plazo, limitar el impacto del cine estadunidense en la sociedad, fenómeno similar al que ocurre hoy en Europa por la globalización que vivimos, según lo muestran los acuerdos-desacuerdos de la ronda de Uruguay del GATT, y porque el tema puede ser abordado desde numerosas perspectivas. He modificado algunas apreciaciones sobre la metodología porque persisten problemas, pese a las correcciones de Fein al texto.

La lectura de la primera versión me sugirió varias ideas en torno a la unión que existe entre política, economía y cine por ser éste, además de un arte, una industria masiva de comunicación que lo convierte en agente poderoso de penetración de ideologías que calan hondo en las sociedades. Una de esas ideas es la experiencia siempre vigente sobre las relaciones entre México y Estados Unidos a través del cine, no sólo por la apertura del TLC, sino también por las negociaciones del GATT; productos ambos de la globalización posmoderna que vivimos. Seré explicito: durante la ronda de Uruguay en el mes de diciembre de 1993, para llegar a un acuerdo y destrabar las negociaciones entre Europa y Estados Unidos, se dejó fuera del tratado a los medios masivos de comunicación audiovisual debido al enfrentamiento de la postura estadunidense de liberalismo en la exhibiciónde películas, contrael proteccionismo europeo de su propia producción. Al seguir a través de la prensa la actitud española frente al problema, recordaba la situación suscitada entre México y Estados Unidos en el año de 1931 descrita en mi libro Medio siglo de cine mexicano, ${ }^{1}$ detallada por Seth Fein en la primera versión gracias a la documentación de archivo.

En efecto, la administración del presidente Pascual Ortiz Rubio elevó en julio de 1931 los impuestos sobre importación de películas con el ánimo de proteger y desarrollar la industria cinematográfica mexicana, que todavía no existía; ni siquiera se había filmado Santa, considerada la primera película de la etapa industrial. La medida afectó sobre todo a los distribuidores estadunidenses, que controlaban 95\% de dicha rama del negocio, quienes suspendieron de inmediato la entrega de películas a los exhibidores, lo cual equivalía a una huelga; además amenazaron con retirarse de México. Al cabo de tres meses, la exhibición entró en crisis porque, en primer lugar, no había películas mexicanas que exhibir puesto que apenas se planeaba la filmación de Santa; en segundo, el gusto del público demandaba el producto estadunidense $y$, en tercer lugar, porque las relaciones con los productores europeos casi habían desaparecido desde la revolución y la primera guerra mundial. Los distribuidores de películas europeas, que debían ser pocos, no tenían en bodega, por tanto, material suficiente para susti-

1 Aurelio De los Reyes, Medio siglo de cine mexicano, Editorial Trillas, México, 1986. 


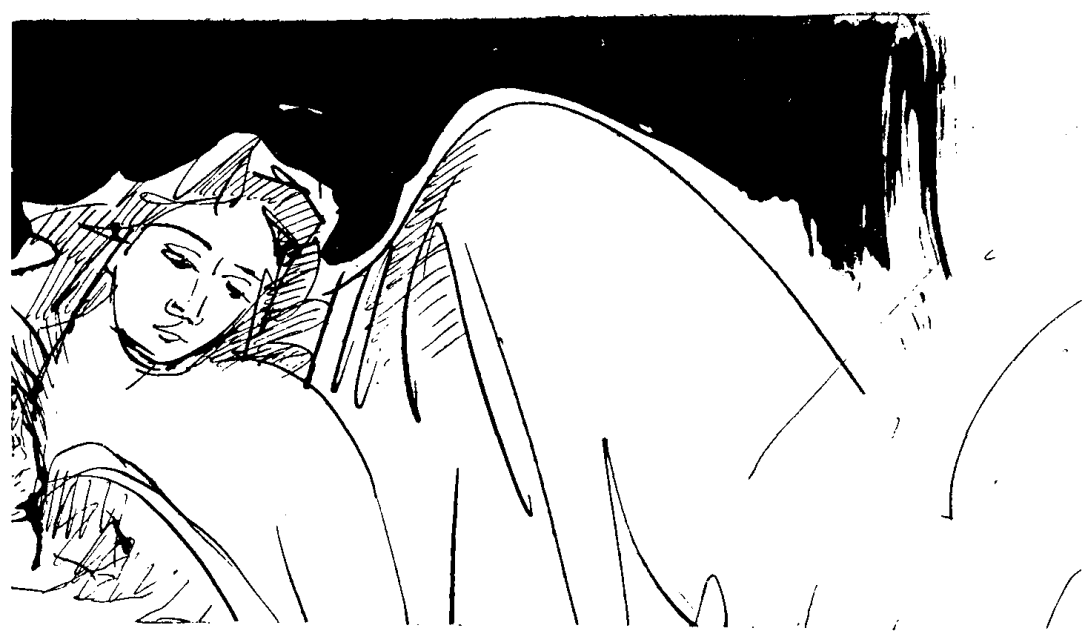

tuir las películas estadunidenses, además de que el gusto del público no puede remodelarse de un día para otro. Aunque los exhibidores veían con simpatía la idea de estimular una industria cinematográfica propia, las circunstancias los obligaron a acudir al presidente para pedir que reconsiderara el aumento en los impuestos. Ortiz Rubio, sensible al argumento del posible desempleo de 50000 personas, ordenó suspender el aumento. Ganó la pre-sión estadunidense.

Hoy en España, como entonces en México, el gobierno, a raíz de la llama. da Ronda de Uruguay y con el apoyo del sector de la producción, emitió un decreto para obligar a los exhibidores a dar trato preferencial a la producción española, además de imponer más condiciones para el doblaje al castellano de películas de Estados Unidos. Los exhibidores, como en México los distribuidores, presionaron con una huelga empresarial para obligar al gobierno a suspender el decreto, además de argumentar que no son ellos los que prefieren el cine estadunidense, sino el público, quien disfruta con la vista y participa del american way of life, igual que el público citadino mexicano de aquellos años, particularmente el del Distrito Federal, como lo señala Fein. Pero, al contrario de lo sucedido en México, el decreto no ha sido suspendido, y el problema actualmente se encuentra en debate.

Los demás países europeos del GATT con industria cinematográfica propia se aprestan también a protegerla. El 
fin del problema es incierto; porque si bien me parece observar una similitud con la situación mexicana de la década de los treinta, particularmente España, por su dependencia tecnológica al igual que México, existen también diferencias. México protegió a una industria que aún estaba en la imaginación de todos, mientras que Europa protege una industria existente y consolidada; de ahí el punto muerto en que cayó la negociación. Todavía más: Suiza, Inglaterra, Francia, Alemania e Italia tienen su propia tecnología, que incluye película virgen, es decir son autosuficientes.

Pero también es cierto que el público europeo de ahora gusta de la película estadunidense, que ha estandarizado la producción y ha borrado, en mucho, las diferencias nacionales; en este sentido, el cine es un claro ejemplo de la globalización posmoderna. Los exhibidores españoles no dejan de tener razón cuando dicen que el público es el que manda, como la tenían los distribuidores mexicanos de la década de 1930 , y para proteger una industria se necesita el apoyo del público porque el cine es ante todo una industria que persigue ganancias económicas. Vale la pena contemplar las medidas que adopten los gobiernos, ya que no pueden prescindir de la preferencia del público.

También la primera versión de la ponencia de Fein me hizo ver que la vecindad de México y Estados Unidos planteó a nuestro país un problema que, por la globalización, se suscita a nivel mundial sesenta años después, en los medios de comunicación audiovisual, aunque es importan- te destacar que no sólo los países europeos que nollegaron a un acuerdo con Estados Unidos cuentan con industria cinematográfica propia, sino también los tercermundistas como México, Brasil, Argentina, Venezuela, India, entre otros, de los cuales desconozco su actitud ante el GATT.

Quizá en Europa ocurra lo que sucede en México: que pese a que desde 1947 existe una ley proteccionista que estipula que $50 \%$ del tiempo en pantalla debe darse al cine mexicano, es letra muerta porque éste se ha alejado del gusto de la cada vez más numerosa clase media de las ciudades, que prefiere películas estadunidenses a pesar de los esfuerzos intermitentes del gobierno desde los años setenta de crear un producto que la satisfaga.

El producto mexicano mayoritario lo consume un público con bajo nivel educativo; es ahí donde el cine mexicano, como en el resto de los países tercermundistas, cuenta todavía con un amplio espacio, lo cual no sucede en el primer mundo.

No creo que México pueda hacer nada en relación con el GATT, puesto que, como dije, el gusto del público se encarga de hacer inoperante la ley proteccionista al preferir cine estadunidense. Quizá la salida para los europeos consista en estandarizar su producción porque la globalización en el medio audiovisual encamina sus metas hacia esto, con lo cual resultan claras las palabras de Fein:

Como hoy, pese a esta retracción de la economía política mundial, las industrias de la cultura de Estados Unidos y el impacto transnacional de la cultura de 
masas estadunidense, continuaron siendo el factor determinante para mantener la influencia de Estados Unidos en el exterior -no obstante el auge de las actitudes sociales y políticas nacionalistas de los gobiernos extranjeros.

Tal parece que ser el "traspatio" de Estados Unidos nos ha convertido, para bien o para mal, en su antesala, por lo menos en lo que a medios de comunicación audiovisual se refiere, porque sin duda la globalización plantea problemas a otros países, similares a los que ya ha tenido México desde tiempo atrás; de ahí la importancia de estudiar las relaciones entre México y Estados Unidos desde cualquier punto de vista en un contexto amplio, pues no cabe duda de que siempre es útil conocer otras experiencias.

Otra de las ideas que me sugirió la primera versión de la ponencia de Fein es la necesidad de estudiar dos aspectos de la historia cinematográfica, hasta ahora, que yo sepa, inéditos: uno, la experiencia del francés Charles Pathé en la organización de su transnacional; y dos, el comercio de película virgen entre México y Estados Unidos. Mantengo estas apreciaciones porque Fein tendrá que enfrentar cuando menos el segundo problema.

El caso de Pathé es interesante pues el cine es sin duda uno de los fenómenos precursores de la globalización, que precede incluso al petróleo. Pathé, dueño de Pathé Frères, productora de películas, de película virgen y de aparatos, sistematizó su empresa alrededor de 1905 y abrió estudios subsidiarios en Estados Unidos, Inglaterra, Alemania y Rusia; asimismo estableció sucursales y agencias en numerosos países, además de firmar contratos de exclusividad con cadenas exhibidoras para circular su producto, con lo cual controló el mercado al mismo tiempo que contrató camarógrafos locales, incluido México, para recibir escenas de los acontecimientos importantes con las que en 1909 editó el PathéJournal, primer noticiario cinematográfico del mundo. Estudiar su imperio nos llevaría a conocer los problemas que enfrentó, incluidos los políticos, para saber si desde entonces diplomacia y cine iban unidos, y las soluciones que dio, ya que seguramente tuvo una confrontación ideológica con países como India, China o Japón; es sabido por la prensa y la televisión que numeroso público de la India rechaza el impacto de la televisión estadunidense -sucedánea del cine- que llega a sus casas a través de la comunicación vía satélite, y lleva a sus últimas consecuencias la penetración de las imágenes en la sociedad. No sé qué hacen los gobiernos al respecto, pues la información recibida es escueta y discontinua. Supongo que nada, y no ha de quedar otro remedio a los inconformes que, si no quieren ver imágenes estadunidenses, deben apagar el receptor.

Vale la pena señalar que al imperio Pathé lo desarticularon tanto la primera guerra mundial, cuando Francia y Alemania entraron en guerra-además de que ésta contrajo el mercado de Pathé, como también la revolución rusaa causa del cambio en las estructuras económicas, políticas y sociales. Como fenómeno globalizador, el imperio del cine estadunidense sustituyó al imperio de Pathé. 
El otro tema que me sugirió el texto de Fein, importante para entender cabalmente las relaciones cinematográficas entre México y Estados Unidos, es la necesidad de estudiar el comercio de película virgen y de aparatos cinematográficos, pues los productores de una y otros, al no tener problemas, no tenían para qué solicitar la intervención de la diplomacia, ni por qué hacer ruido, como los productores y exhibidores, debido a lo cual su actitud no ha sido percibida por los historiadores.

México sólo intentó proteger su producción y exhibición y no fomentar una tecnología; por tanto no afectó los intereses de Eastman, de Power o de otras empresas. Proteccionismo antes que perjuicio, benéfico para aquellas compañias ya que era, de hecho, un cheque al portador para incrementar las ventas. Me parece que hasta ahora se desconoce la actitud asumida por dichas empresas, en casos extremos, sobre los conflictos entre México y Estados Unidos en materia de cine; no sabemos, por ejemplo, al menos yo, si durante situaciones conflictivas amenazaron, por solidaridad, con evitar la venta de película virgen, con lo cual aumentaban su presión sobre el gobierno mexicano. O se abstuvieron de un apoyo por temor a que de inmediato entrasen a México empresas europeas, pues en este renglón no había necesidad de cambiar el gusto del público, lo cual facilitaba las cosas.

La primera versión del texto de Fein nos hacía ver cómo el cine mexicano finalmente se convirtió en un competidor de peso del cine estadunidense, tanto en México como en América Latina. Tendió la "cortina de nopal", de que hablo en Medio siglo de cine mexicano, al desplazar a las películas estadunidenses en el gusto del público. Al respecto, sería interesante saber en qué medida el auge del cine mexicano incrementó las ventas de Eastman y de aparatos estadunidenses, o si los productores utilizaron película virgen de otros países en detrimento de las compañias estadunidenses, y en qué medida las condiciones europeas fortalecieron o debilitaron este aspecto del negocio entre Estados Unidos y México. Es verdad que durante la segunda guerra mundial se intentó suprimir la venta de película virgen a México, de la misma manera que se hizo con Argentina por su simpatía con los países del Eje, por lo cual se desplomó su industria; pero no era Eastman quien deseaba aplicar la medida, sino que, de llevarse a cabo, lo haría por presión del gobierno de Estados Unidos, pues, como quedaba claro en el texto de Fein, el cine y la diplomacia suelen ir unidos por tratarse de un medio de comunicación masiva.

Este aspecto del negocio cinematográfico, la venta de película virgen y de tecnología, nos hace ver que la independencia de la industria mexicana de los intereses de Hollywood durante su etapa de expansión, a la que se refería Fein a raíz del éxito de la comedia ranchera en México y América Latina, era relativa, pues si bien podía competir con algunos de los intereses de Hollywood, no había resuelto un problema básico: crear una tecnología propia, por lo cual la industria cinematográfica mexicana continuaba tan de- 


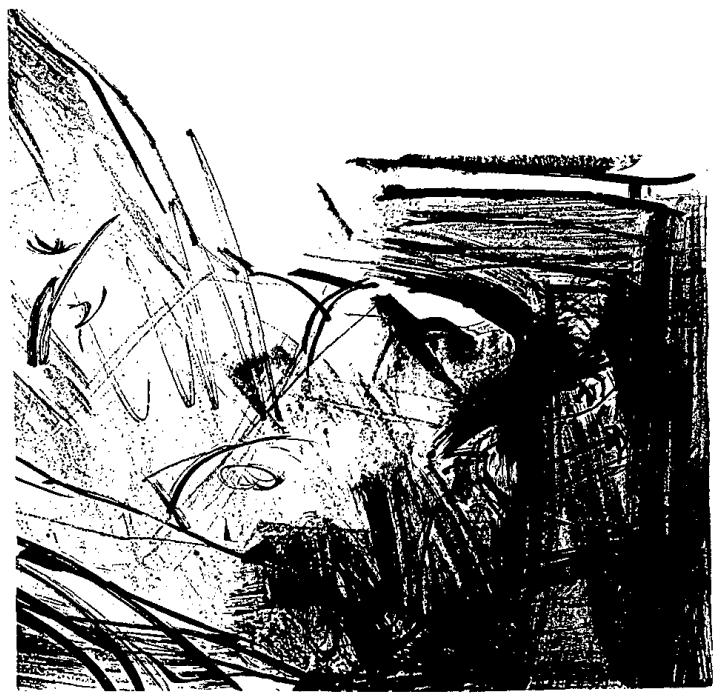

pendiente de Estados Unidos como lo ha estado siempre, aspecto que traté en 80 años de cine en México, basado en el archivo de la Oficina de Marcas y Patentes, de la entonces Secretaría de Industria y Comercio.

\section{II}

Estudiar el cine en un sentido amplio, más allá de las películas, permite adentrarse en la urdimbre y la trama de un tejido que se conecta con múltiples aspectos de la sociedad, y por tanto de la historia, de la política, de la estética, de la economía. El resultado suele ser un punto de vista a veces contradictorio o complementario al brindado por la historia estrictamente económica o política, como lo probaba el texto de Fein, quien después de analizar, a través de la documentación que contenían los Archivos Nacionales de Washington, la relación entre el gobierno de México y el de Washington en materia cinematográfica durante los últimos años del gobierno de Cárdenas, incluido 1938, año de la expropiación petrolera, concluye categórico: "Después de 1938 (en muchas formas, las relaciones [cinematográficas] de Estados Unidos y México se hallaban más bien en un punto alto, no bajo)".

En su ponencia, Alan Knight explica las causas de ese acercamiento en un momento de tensión, con lo cual desmiente los rumores de una tensión en el más alto nivel.

Fein continúa: 
El Estado mexicano participó en el desarrollo de un sistema de medios masivos internacional -progresivamente dirigido por el Departamento de Estado pero operado por instituciones educativas privadas y medios masivos respectivos.

Se refería a las complejas actividades de la Fundación Rockefeller, del consorcio petrolero de Nelson Rockefeller, propietario de la Standard Oil Company, afectado por la expropiación petrolera, con lo cual también aclara una situación desconocida para mí. Concluye Fein:

En otras palabras, como la fase conservadora del imperialismo corporativo de Rockefeller (que apuntaba a la acumulación económica) llegaba en México a su fin, una fase liberal de imperialismo filantrópico, dirigido al entramado social, estaba comenzando.

Aspecto que Fein mantiene en la tercera versión de su texto.

\section{III}

La primera versión de la ponencia de Fein hablaba, como indica su título, de la política exterior de Estados Unidos en relación con el cine y el Estado mexicanos, apoyado fundamentalmente en documentos depositados en archivos estadunidenses, en prensa y en bibliografía complementarias. La versión a comentar no alteró sustancialmente el contenido, como lo indica su título "Film and Mexico-United States Cultural Relations in the 1930s", apoyada ahora en información proveniente del Archivo Histórico de la Secretaría de Relaciones Exteriores de México. Pese al propósito de Fein de mejorar, el aspecto político queda menos dibujado que en la primera versión: "En este ensayo se analiza el papel del cine en las relaciones políticas, ideológicas y culturales entre México y Estados Unidos durante ese periodo", porque persisten problemas metodológicos señalados en la primera versión del comentario, susceptibles de ser corregidos en la versión definitiva del estudio, puesto que se trata de una investigación en proceso.

Dos son los problemas que percibo:

a) Un enfoque estrecho en no pocos de sus aspectos.

b) Limitado uso de fuentes complementarias en detrimento de los significados de la información proveniente de archivos.

En varios aspectos queda manifiesta la ausencia de una perspectiva más amplia al enmarcar la actuación del gobierno estadunidense; por ejemplo, me parece necesario enfatizar la diferencia entre la política de Hoover y la de Roosevelt en relación al cine, que debió ser notable a pesar de que ambos actuaron dentro del fenómeno de la depresión económica. La primera versión del texto de Fein dejaba traslucir con claridad un cambio notable en objetivos y métodos de la política de una y otra administraciones; un apoyo de Hoover casi incondicional a los distribuidores a través del Departa- 
mento de Estado y de la diplomacia frente a una cautela de la administración de Roosevelt, al menos al inicio de su gobierno, lo cual se diluyó en la versión a comentar.

En la intervención de Alan Knight en la mesa redonda quedó claro que Hoover diseñó la política del buen vecino y Roosevelt la desarrolló, aspecto que Fein deja un poco más claro en la tercera versión de su texto, aunque no del todo, lo cual considero se debe enfatizar en futuros textos.

Digo un poco más claro porque ahora dicha política queda más enun. ciada que descrita, lo contrario a la primera versión en la que hablaba sobre las medidas que de inmediato tomó la administración de Roosevelt en relación con el conflicto que enfrentaban los distribuidores de películas estadunidenses por el proteccionismo del gobierno mexicano, según el siguiente párrafo de la primera versión:

Daniels (el embajador) declinó verse envuelto en la disputa de Hollywood. Recomendó que la industria del cine estadunidense esperara hasta después de la World Economic Conference que tenía lugar en Londres, donde Estados Unidos perseguía el establecimiento de un Nuevo Trato de política exterior que buscaba abrir mercados extranjeros a través de un amplio y recíproco convenio de tarifas. En cualquier caso, Daniels sentía que un acuerdo cinematográfico podía salir de ahí, de Londres, entre Estados Unidos y México.

O en este otro:

El Departamento de Estado y Daniels rechazaron el cabildeo de Hollywood en Washington y México por la gestión diplomática de Montevideo. Ellos no querían interrumpir el trato de los objetivos económicos y políticos más amplios, referidos a la política extranjera de Estados Unidos en el hemisferio occidental, que se perseguía en Montevideo, el más importante foro internacional para la Política del Buen Vecino de Franklin Roosevelt.

Me parece necesario que Fein precise en estudios futuros las diferencias básicas entre la política seguida por Hoover y Roosevelt, en lugar de soslayarlas, resaltando dos aspectos: la política de Hoover, describiendo la nueva política y dando la trayectoria de los nuevos encargados de la diplomacia, y quizá las órdenes emitidas al cuerpo diplomático al inicio de la nueva administración.

El texto ganaría en claridad y facilitaría comprender mejor la actuación del gobierno estadunidense, lo cual podría llevarse a cabo en un no muy extenso párrafo en la introducción o en notas de pie de página, e ir explicitando las diferencias en el transcurso del desarrollo con unas cuantas palabras, pues Fein posee la información por la procedencia de sus fuentes, los archivos de las secretarías de Estado de los gobiernos mexicano y estadunidense.

El problema señalado obedece al manejo de la cronología. Dada la procedencia de la información y la presión ejercida por las compañías y el gobierno estadunidense sobre el gobierno mexicano, el estudio debe enmarcarse en la cronología de la historia estadunidense, lo cual daría al estudio mayor cohesión y se entendería 
cabalmente el proceso del objeto de estudio. De esa manera se clarificarían los matices de la política del buen vecino, que para 1939 lleva a la filmación de Juárez por compañías estadunidenses, e incluso la disidencia en la visión del buen vecino por The March of Time.

Otro aspecto que no resultaba claro en la primera versión y que pese a las modificaciones persiste se refiere a la actitud de las compañías productoras y exportadoras estadunidenses de películas, las cuales se encontraban en una situación peculiar durante la depresión pues su economía era afectada por la crisis del 29 y, además, por el fracaso del cine sonoro en todo el mundo, lo cual las obligó a filmar versiones no sólo en español de las películas, como sugiere Fein, sino en francés y alemán.

Así pues, las compañías enfrentaban una crisis por partida doble: el fracaso del cine hablado en inglés en el mundo y la crisis económica iniciada en Estados Unidos en 1929, para nada destacado por Fein en ninguna de sus versiones. De tal manera que el inicio del cine sonoro, en lugar de ser una expansión, como señala Fein, era para la industria cinematográfica de Estados Unidos una aguda contracción. De ahí la preocupación tanto del gobierno estadunidense como de las compañías de evitar polémicas con otros países respecto de la representación de personajes de diversas nacionalidades en el cine, polémicas que se traducirían en prohibición de películas y, por tanto, en inversiones muertas.

Italia, Francia y Alemania reaccionaron negativamente frente a la inva- sión de las películas estadunidenses habladas y procuraron fomentar su propia industria, de la misma manera que México; por tanto, Hollywood debía cuidar más la representación de los estereotipos de otras nacionalidades para no herir la susceptibilidad de los paises, que le ocasionarían boicots, como el queaplicó exitosamente México en 1921 a la producción estadunidense y que contó con la simpatía de América Latina, España, Italia, Francia y Alemania.

El boicot aplicado por México en 1921 obligó a la intervención en el negocio del cine, no por primera vez sino una vez más, del Departamento de Estado a pesar de no haber relaciones diplomáticas entre ambos países, al grado de que hubo de firmarse un acuerdo entre la Motion Picture Producers and Distributors of America y el gobierno mexicano; negociación similar emprendida con los gobiernos de los países citados con anterioridad. Alemania, cuyos nacionales eran particularmente satirizados a raíz de su derrota en la primera guerra mundial, aprovechó la experiencia mexicana para presionar y logró el retiro de circulación de The big parade. Italia prohibió las películas de Rodolfo Valentino. España, Revenge, con Dolores del Río, entre otras.

Respecto de la representación de los nacionales de otros países en el cine estadunidense, se convierte en consulta indispensable el libro de $\mathbf{K e}$ vin Brownlow, Behind the mask of innocense, pues el problema no fue exclusivamente con los mexicanos; así también el artículo del suscrito "Las películas estadunidenses deni- 
grantes y el gobierno del general Obregón", publicado en el número 4 de la revista Intermedios, en el cual queda de manifiesto el trasfondo políticodiplomático del problema entre ambos países durante la década de los años veinte, que permite entender con mayor precisión la actuación de am. bos gobiernos en la década siguiente, sobre todo el deseo de los gobiernos de Españay México de firmar un acuerdo para presionar a las compañías productoras para evitar en las películas la representación de imágenes ingratas de los tipos de ambos países, con lo cual quedaría clara la frase de Fein:

Esto [el estímulo del Estado al cine mexicano de los años treinta] también provocó que políticas exteriores mexicanas impidieran la proyección de películas que el Estado considerara como denigrantes.

El fracaso de la sonorización y de las películas habladas en otros idiomas obligó a las compañías a replantear su producción y las hizo hipersensibles a cualquier medida proteccionista, sobre todo de México dada su cercanía, al cual consideraban esencial para la recuperación rápida de los costos. Lo anterior explica, por una parte, la agresiva actitud de los distribuidores de películas estadunidenses frente al gobierno mexicano, de que hablaba Fein en la primera versión, pero también el establecimiento de la política del buen vecino, la cual llevaría al mismo resultado de la consolidación de la hegemonía estadunidense, sólo que a mediano plazo, como lo señala Fein en su texto definitivo.
La ausencia de un contexto más amplio para explicar el fenómeno estadunidense vuelve a hacerse palpable al no explicitar las consecuencias que trajo consigo el fracaso en casi todos los países del cine sonoro estadunidense por estar hablado en inglés, y el de las películas habladas en otros idiomas, que creó las condiciones ideales para el surgimiento de las cinematografias sonoras nacionales en Italia, Francia, España, México, Argentina, lo cual Fein puede consultar en no pocos libros como Historia del cine mundial de Georges Sadoul, Historia del cine italiano de Pierre Leprohon, Medio siglo de cine mexicano, del suscrito, o en enciclopedias cinematográficas que se encuentran en bibliotecas especializadas.

Por otra parte, la crisis por la que atravesaron las compañías filmicas estadunidenses la describen Gaizka de Usabel en The high noon of american pictures in Latin America, Ian Jarvie en Hollywood's overseas campaign:The north atlantic movie trade, 1920-1950 y Margaret Dickson y Sarah Street en Cinema and State: The film industry and the british government, 1927-1984, citados por el propio Fein en la primera versión de su libro, además de estar documentadas minuciosamente en las revistas de viajes consultadas por Fein. De tal manera que una mirada cuidadosa nos releva que tuvieron que resolverse problemas diplomáticos y políticos dificiles antes de consolidar la hegemonía estadunidense, lo cual Fein soslayó en la primera y última versión de su texto, pese a los comentarios que le hice en este sentido. 
Es sabido que la representación de la figura de Villa en el cine ha sido problemática no sólo en el cine estadunidense, sino también en el cine mexicano, lo cual creo que se debe aclarar al hablar de la filmación de jViva Villa! para entender cabalmente la sensibilidad del gobierno de México ante el contenido del argumento. Problema que, por otra parte, se relaciona íntimamente con el de la representación del mexicano en la pantalla, que para 1917 el gobierno mexicano lo consideró un problema y enfrentó el gobierno del general Obregón, como se dijo, e hizo imprescindible la negociación entre los productores estadunidenses y el gobierno mexicano cuando se trataba de representar personajes importantes de la historia de México, como Villa y Juárez. De tal manera que las negociaciones entre el gobierno de México y la Motion Pictures Producers and Distributors of America sobre la filmación de ;Viva Villa! al inicio de los años treinta era un paso obligadamente rutinario. Por la misma razón, esa asociación vigilaba con mucho cuidado los pasos de los productores en relación con la representación de dichos personajes, puesto que desde su fundación, en 1922 , se había visto envuelta en los problemas surgidos con México.

¿Qué había detrás del interés de los productores por volver sobre la figura de Villa al inicio de los años treinta? Sin duda consolidar un mercado que se les desplomaba por el fracaso del cine sonoro y de las películas habladas en español, pues según Fein: "Varios estudios cinematográficos estadunidenses pensaron en hacer una pelícu- la sobre Pancho Villa a principios de los años treinta."

Por otra parte, según Fein, dicha película encontró numerososobstáculos para su realización, al grado de terminarla en Hollywood y no en México, como se había planeado. Por razones que desconozco, Fein soslaya precisar tales problemas.

La misma ausencia de perspectiva la encuentro cuando Fein habla del proteccionismo del gobierno mexicano a la industria cinematográfica. De la lectura del texto de Fein se deduce que dicho proteccionismo se inicia en el momento de surgir el cine sonoro mexicano.

Conflictos culturales de larga data sobre representación, entre Hollywood y México, estimularon al Estado mexicano a apoyar el desarrollo de una industria propia de cine sonoro, en especial, a principios de los años treinta.

Pero el proteccionismo era un propósito tradicional del Estado mexicano, surgido al mismo tiempo que el de combatir la imagen negativa de los mexicanos en las películas estadunidenses, hacia 1917, codificado en el decreto de censura de Venustiano Carranza de 1919, lo cual estudié en los libros Vivir de sueños y Medio siglo de cine mexicano. Fein no aclara la diferencia entre el ayer y los inicios de la década de los años treinta; esto es, no precisa las características del proteccionismo mexicano en los años tempranos de dicha década; aspecto que quedaba mejor expuesto, aunque de manera insuficiente, en la primera versión, por no enmarcar su informa- 


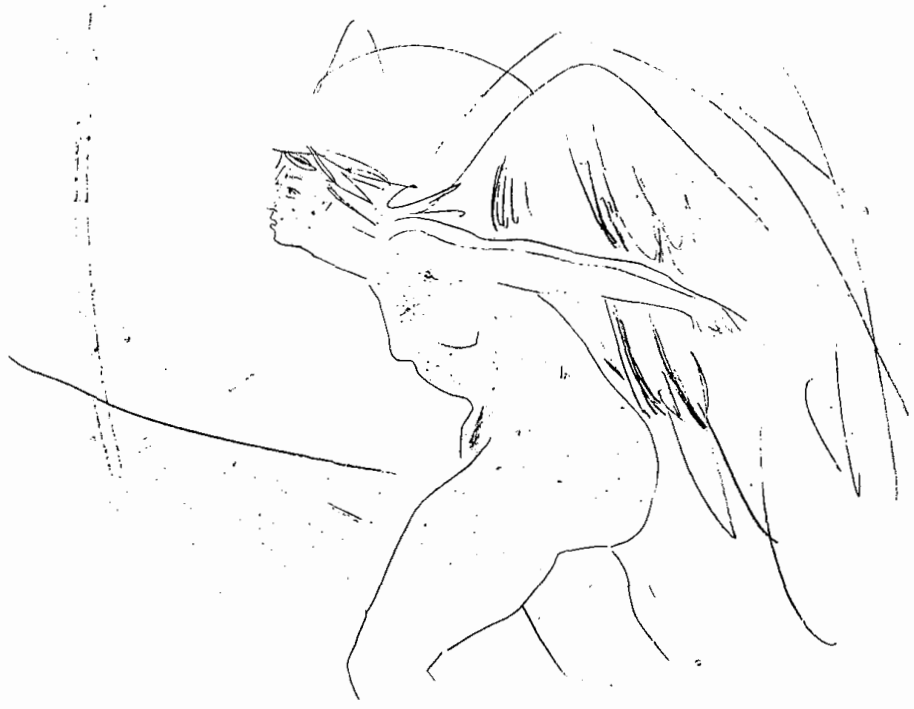

ción proveniente de archivo con bibliografia complementaria.

El problema de un contexto más amplio vuelve a quedar de manifiesto cuando el gobierno mexicano, pese a su proteccionismo, tiene que aceptar la influencia estadunidense, obligado por el desarrollo del nazifascismo, que lo convierte en aliado de Estados Unidos, de tal manera que en un lapso de nueve años se revirtió la situación y, en lugar de encontrar oposición, las películas estadunidenses contaron con el beneplácito del gobierno.

Después de estallar la segunda guerra mundial, cuando se profundizaron las relaciones entre los dos gobiernos, el gobierno mexicano trataba de explotar la propaganda estadunidense para sus propios objetivos, tanto internacionales como domésticos.

En el transcurso de unos cuantos años fueron las cinematografias española, alemana e italiana las que se convirtieron en indeseables.

La situación cambió más por la situación internacional

a medida que la representación hollywoodense de México se hizo más positiva, la ideología oficial del Estado mexicano y sus políticas estuvieron menos enfrentadas a Estados Unidos, y a medida que se desarrollaron estructuras transnacionales entre los dos países, a finales de los años treinta, desapareció la oposición del Estado mexicano a la postura dominante de Hollywood en la producción de historias populares mexicanas. 
Pero la representación de los mexicanos se cuidaba desde la firma de los acuerdos entre la Asociación de Productores y el gobierno mexicano en 1922. Amerita profundizarse en el estudio de las películas que representaban a los héroes mexicanos y a los mexicanos mismos en las películas estadunidenses de los años trienta, visto el fenómeno con perspectiva desde los años veinte.

Fein se refiere ampliamente al cambio de la situación internacional para explicar la película Juárez, sin subrayar el cambio tan radical que sufrió la política proteccionista del gobierno mexicano en el transcurso de unos cuantos años, lo cual imprime más dramatismo a su conclusión:

Conforme el papel del cine en el gobierno estadunidense se profundizó su penetración en México se incrementó. Se instauraron nuevos lazos de organización de tiempos de guerra entre Hollywood y la industria mexicana del cine, reforzados por las ligas ideológicas entre el Estado mexicano y el gobierno estadunidense, aumentadas más adelante durante la guerra fría.

Señalaré otros dos problemas, la ausencia de información sobre algunos personajes o instituciones importantes y la falta de revisión de las películas ¿Viva Villa!', asequible en disco lasser, $y$ de The girl of the Rio, conservada en los archivos fílmicos de UCLA y de la Biblioteca del Congreso para que Fein tuviese otro elemento de juicio y emitiera una opinión fundamentada sobre el argumento, la actuación y la escenografia a fin de explicar la procedencia o no de las actitudes del gobierno mexicano.

De Abelardo Rodríguez, que precede a Cárdenas en el gobierno, Fein sugiere haber estado involucrado en el negocio cinematográfico sin aportar mayor información; no se sabe la importancia de Genaro Estrada, impulsor de un acuerdo entre México y España para proteger la imagen de ambos países en películas estadunidenses; ni de Ramón Puente, que fuera uno de los últimos secretarios particulares de Villa, lo cual se puede encontrar en el estudio de Enrique Krauze dedicado al caudillo norteño.

Tampoco queda claro quién era Willy Hays ni por qué tenía tanta influencia en la industria cinematográfica estadunidense, ni quiénes integraban la Motion Picture Producers and Distributors of America, ni por qué surgió dicha Asociación, aspectos importantes para la comprensión de los hechos narrados por Fein.

En cuanto a los integrantes de la Motion Picture Producers, su fundación y objetivos, puede encontrarse información en numerosos libros, como en el de Benjamin B. Hampton, History of the american film indus. try. From its beginnings to 1931, el de Lewis Jacobs, The rise of the american film, y otros.

Fein no acaba de precisar el tipo de película que era The March of Time, al que repetidamente llama noticiero sin ser propiamente tal. Un noticiero tenía una periodicidad promedio de dos veces a la semana, aunque los había semanarios, contra la edición mensual promedio de The March of Time. Los noticieros se caracterizaban por con- 
tener cápsulas informativas, de menos de un minuto de duración cada una, sobre hechos considerados importantes sucedidos en el lapso de la aparición de cada número: la depresión, sucesos nacionales, noticias extranjeras, modas, viajes, ejército, etcétera, como Fox Movietone News, Paramount News, Hearst Metrotone News, etcétera, frente al tratamiento monográfico, con un promedio de diez minutos de duración de cada uno de los números de The March of Time, lo cualle daba una característica peculiar.

Tanto los noticieros como The March of Time los aborda ampliamente Raymond Fielding en sus libros The american newsreel, 1911-1967 y The March of Time, 1935-1951; y sobre este último nos informa:

Había también por ahí unas pocas series, las cuales trataban distintos sucesos y que eran un híbrido entre noticiero y documental, entre reportaje y comentario. Uno de éstos fue The March of Time, una especie totalmente diferente de tema en el cortometraje [...] Fue producido por el fotógrafo de noticieros Louis de Rochemont para los editores de la revista Times and Fortune. Se estrenaba cada mes, y esta desusada serie perduró dieciséis años. ${ }^{2}$

The March of Time se inscribe dentro del cine de propaganda encaminado a transformar la sociedad, objetivo tomado del cine soviético, pero en este caso utilizado con una variante de 180 grados, ya que pretendía consolidar el sistema capitalista, como queda

\footnotetext{
${ }^{2}$ Raymond Fielding, The american newsreel. 1911 -1967, The University of Oklahoma Press, Oklahoma, 1972.
}

claro en los números dedicados a México comentados por Fein.

Desde luego que el estudio de Fein posee numerosos aciertos, según ya lo he señalado al principio de estos comentarios, como la lectura de la pelícuIa Juárez, pero necesita completar su información de archivo con la proveniente de archivos mexicanos así como apoyarla con un uso adecuado de la bibliografia complementaria para evitar el mecanicismo que actualmente comunica, al ocuparse casi con exclusividad de las actuaciones cupulares de los gobiernos de Estados Unidos a través de los titulares de secretarías de Estado o de embajadores, o a través de presidentes o representantes de asociaciones de productores y distribuidores de películas. Ello para ofrecernos un estudio con mayores matices y precisiones de los hechos y de sus significados, pero, sobre todo, una perspectiva amplia pues la globalización que vivimos nos exige a los investigadores mayor amplitud en los puntos de vista para llegar a una "historia mejor comprendida que mal entendida", como lo señala Marc Bloch, y sin duda es propósito de Fein, según se desprende de la lectura de sus primeras páginas:

Estos asuntos deben ser interrelacio. nados, puesto que cada uno afecta al desarrollo del otro, y solamente el examen de ambos permite la comprensión exhaustiva de los procesos que determinaron la economia política y cultural de las relaciones de Estados Unidos y México en los años treinta, y el desarrollo de la política exterior estadunidense respecto de los medios masivos de comunicación. 


\section{SECUENCIA}

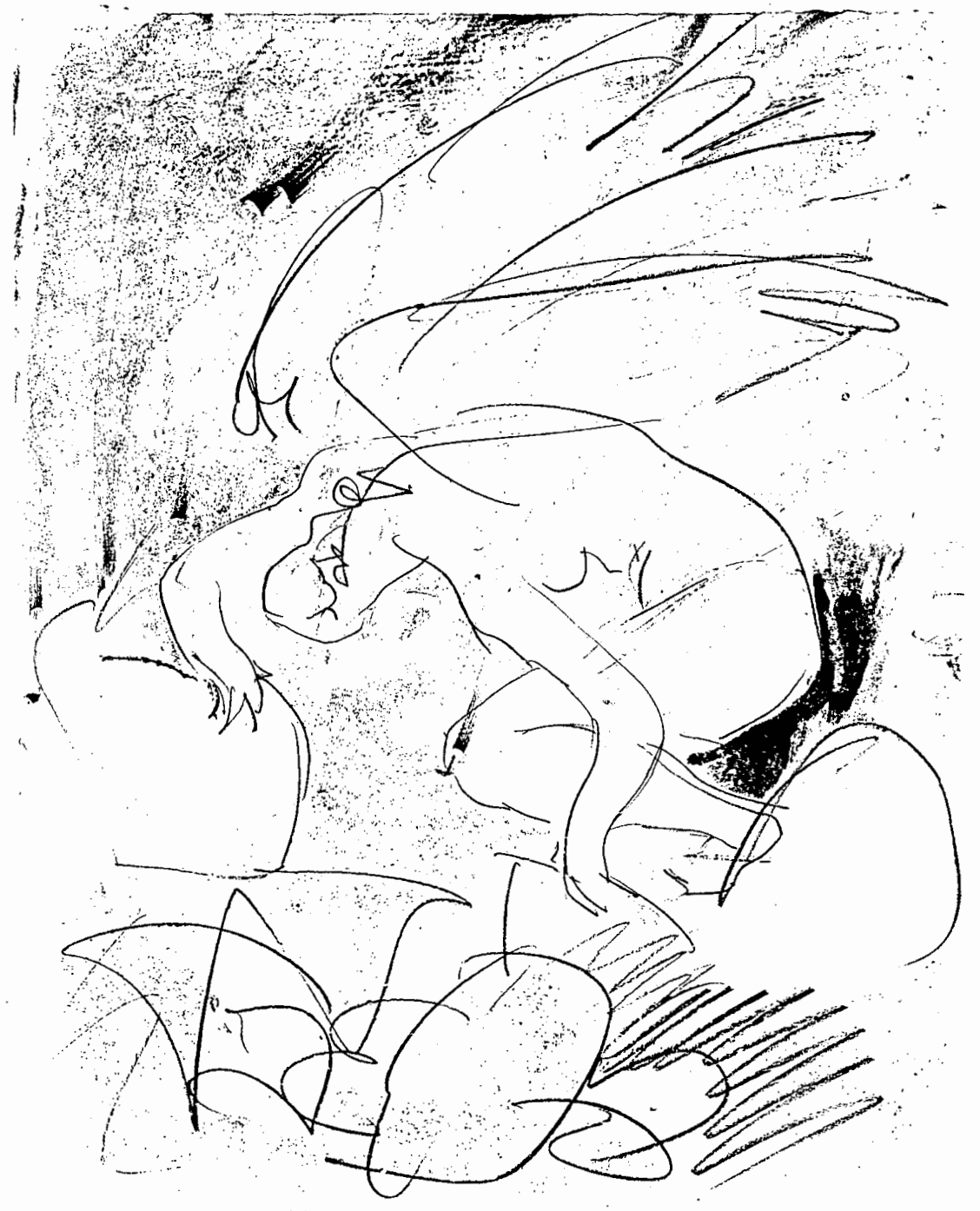

